\section{Comparison of postoperative intraocular pressure in patients with Densiron-68 vs conventional silicone oil: a case-control study}

Correction to: Eye (2009) 23, 190-194; doi: 10.1038/ sj.eye.6703055; published online 7 December 2007

Owing to a publishing error in the list of authors, the author's name was spelt incorrectly.
D Wong, I Kumar, SA Quah, H Ali, X Valldeperas and MR Romano

The correct spelling is $\mathrm{X}$ Valldeperas.

The publisher would like to apologise for this mistake. 